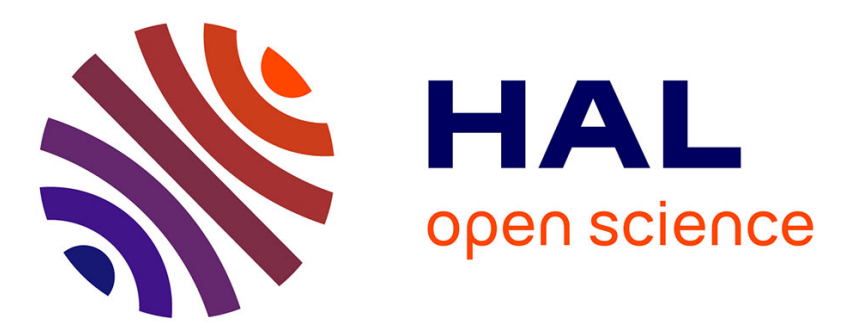

\title{
The Health Consequences of Mozambican Civil War : an Anthropometric Approach
}

Patrick Domingues

\section{To cite this version:}

Patrick Domingues. The Health Consequences of Mozambican Civil War: an Anthropometric Approach. 2010. halshs-00461513

\section{HAL Id: halshs-00461513 \\ https://shs.hal.science/halshs-00461513}

Submitted on 4 Mar 2010

HAL is a multi-disciplinary open access archive for the deposit and dissemination of scientific research documents, whether they are published or not. The documents may come from teaching and research institutions in France or abroad, or from public or private research centers.
L'archive ouverte pluridisciplinaire HAL, est destinée au dépôt et à la diffusion de documents scientifiques de niveau recherche, publiés ou non, émanant des établissements d'enseignement et de recherche français ou étrangers, des laboratoires publics ou privés. 


\section{Documents de Travail du Centre d'Economie de la Sorbonne}
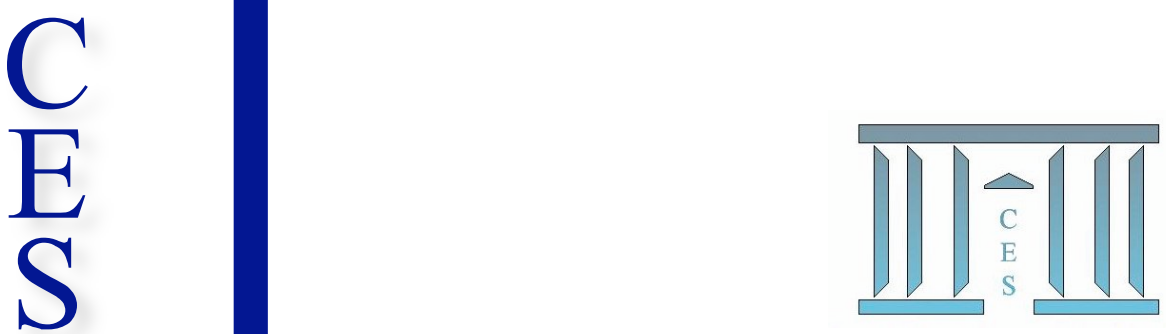

The Health Consequences of Mozambican Civil War :

an Anthropometric Approach

Patrick DOMINGUES

2010.10

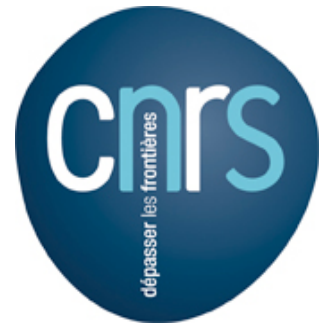

Maison des Sciences Économiques, 106-112 boulevard de L'Hôpital, 75647 Paris Cedex 13 


\title{
The Health Consequences of Mozambican Civil War: an Anthropometric Approach
}

\author{
PATRICK DOMINGUES* \\ Université Paris 1 Sorbonne - CES
}

This Draft January 2010

\begin{abstract}
The consequences of civil war have been widely analyzed, but one of its aspect, yet important, remains marginally investigated: the human cost of the combats. Indeed, most of recent literature has focused on the numbers of dead and wounded, while little scope has been given to survivors' health, whether they have been injured or not. Given that survivors are the ones who bear the burden of reconstruction, the evaluation of the health costs of civil conflict, is therefore crucial for the conception and the implementation of proper economic policies. This paper is an attempt in this direction. It aims at assessing the impact of the fifteen year long Mozambican civil war on the long-run health and nutritional status of adult women, measured by their height-for-age z-score (HAZ). In this perspective, two sets of data are used: the household survey data derived from Demographic and Health Survey (DHS+ 2003) which provides individual level information and in particular a set of anthropometric measures combined with an original, event dataset reporting the timing and location of battles and military actions that took place during this war. In accordance with the existing literature on this topic, I find that women who were exposed to the conflict during the early stages of their lives have, on average, a weaker health in comparison to other women, reflected by a lower HAZ. Using the Infancy-Childhood-Puberty Curves, a concept given by the medical literature studying the human growth process, I point out that this negative effect depends both on the age of entry into civil war and on the number of months spent in conflict. Furthermore, this study indicates that months of civil war before a woman's birth also have a negative impact on her health highlighting thus the importance of the prenatal conditions. Moreover, as recent works have shown, a poor health status induces other adverse effects in the long run. All of these effects emphasize the importance of preventing civil wars and stopping ongoing conflicts.
\end{abstract}

Keywords: civil war, health, nutrition, anthropometry

JEL Classification: O12, O55, I12, H56.

\footnotetext{
${ }^{1}$ I would like to thank Michen Cahen for helping me in gathering information on the history of Mozambican civil war. I am grateful for access to the Demographic and Health Survey database kindly provided by Macro International Inc. I specially tank Thomas Barré for very useful discussions and assistance. I would like also tank for comments and advice Jean-Louis Arcand, seminar participants at the Fifth Households in Conflict Network Workshop (2010), and the members of the development and globalization research group.

* Contact information: Patrick Domingues, Maison des Sciences Economiques, 106-112 Boulevard de l'Hôpital, 75013 Paris. e-mail : patrick.domingues@univ-paris1.fr
} 


\section{1 - Introduction}

A country sinking into civil war is confronted with a process of self destruction in which it damages its economic growth's potential (to such a point, that Paul Collier referred to civil war as "development in reverse"). ${ }^{2}$ Also as Fearon and Laitin (2003) mentioned, civil war is far from being uncommon. Indeed, between 1945 and 1999, 127 civil wars broke out in 73 states, and lasted on average six years. Each has caused at least 1,000 deaths and 25 of them were still going on in 1999.

The frequency and the high destructive capacity of civil wars have prompted a large array of analyses in recent years. ${ }^{3}$ Some authors like Singer and Small (1994) set up a database on civil wars. Others have focused on the causes of the civil conflicts (Collier and Hoeffler (1998, 2004)), or on their duration (Collier, Hoeffler and Soderbom (2004) and (Elbadawi and Sambanis (2000)). Some others authors like Hoeffler and Reynal-Querol (2003) have focused on the consequences and on the costs of civil war on the country itself, while others like Murdoch and Sandler (2002) analyzed the spread of these consequences to neighboring countries.

As highlighted by the existing literature, civil wars may have devastating effects on an economy on several grounds. It has been evidenced that civil wars have a negative impact on all determinants of economic growth. ${ }^{4}$ By killing a considerable number of individuals, civil wars reduce the workforce of a country (Ghobarah, Huth and Russett 2003, 2004). They also destroy physical capital and hamper its accumulation process (Collier (1999)). Other consequences of civil wars include human capital destruction and specifically the level of education of the population (Shemyakina (2006)). Indeed, its stock decreases with the number of deaths in the population and its accumulation is curbed notably through the decrease of school enrolment and years of schooling. Civil wars have also a negative effect on institutions and on the social cohesion.

\footnotetext{
${ }^{2}$ Collier, P. (2004), "Development and Conflict", Centre for the Study of African Economies_Centre for the Study of African Economies, Department of Economics, Oxford University, October 1st, 2004.

${ }^{3}$ See Blattman and Miguel (2009) for a recent survey of the theoretical and empirical literature on the determinants and consequences of civil war. Furthermore, Justino $(2008,2009)$ provide a survey of the microlevel literature on civil conflict.

${ }^{4}$ Tilman Brück (1997) provides an analysis of some macroeconomic channels operating in an economy involved in a war context, and evidence drawn from the Mozambican case.
} 
The aim of this paper is to estimate the impact of civil war on another determinant of growth: the health capital (Gupta and Mitra (2002)). This suggests studying either individuals who died during the conflict or those who survived. While the former have been widely analyzed, we focus in this paper on the latter. That is, we question the durable consequences of a civil war on the health of individuals who survived.

As mentioned above, the first case to be considered is that of those who died during the conflict. They are not only combatants but also civilians, both being either victims of direct violence or of the conflict's indirect consequences, such as disruption of the health system). ${ }^{5}$ Several studies are also evaluating the consequences of civil war in terms of number of dead. As cited by Fearon and Laitin (2003), 16.2 million deaths are directly attributable to the identified 127 civil wars that occurred between 1945 and $1999 .^{6}$ In recent years, war related deaths enumeration has been the subject of critical analysis leading to a better estimate of mortality, for example in Darfur (Guha-Sapir and Degomme. (2006)) and in BosniaHerzegovina (Tabeau and Bijak (2005)).

Analyses based on mortality rates are useful to evidence the destructive power of civil wars and to stress the need for preventing them and protecting civilians. However, they are of little help for designing and implementing policies in the post-conflict period. For this purpose it seems appropriate to focus on survivors. It should be kept in mind that civil wars do not only kill; but they also lead to many other human tragedies, as mutilations, starvation, forced migration, the spread of epidemics, the destruction of the sanitary and health infrastructures, and they deprives population of accessing the remaining infrastructures. Consequently individuals surviving to a conflict do not only have a permanently damaged health capital (often translating into early death or at least into a decrease of the number of healthy years of life), but they also have to live in an unhealthy environment.

Survivors have suffered both from direct and indirect consequences of civil conflicts, and at the end of the war their health is deteriorated to some degree. On this point, Davis and Kuritsky (2002) conclude that the health outcomes of Sub-Saharan African countries that were involved in a conflict are worse than those of countries that remained at peace. Similarly, Stewart and Humphreys (1997) find that infant mortality rate is significantly higher

\footnotetext{
${ }^{5}$ Pedersen (2009) provided a comprehensive review of the researches on the different channels through which civil war influence health.

${ }^{6}$ This intrastate war data derive from Singer and Small (1994), updated to include the Kargil and Eritrean wars.
} 
in countries that were affected by armed conflict than in others. Moreover, Bundervoet, Verwimp and Akresh (2009) highlight the durable impact of the Burundi civil war on children's health status since each additional month of war exposure decreases a child's height for age z-score by 0.047 standard deviations. With the same type of anthropometric indicator, Arcand and Djimeu Wouabe (2009) found that in the case of the Angolan civil war, the intensity of the conflict negatively impacts children health. Finally, Blattman and Annan (2007) show, among other results, that child soldiers are more likely to have persistent injuries. Therefore, depending on the virulence with which the war has affected survivors' health, their life expectancy will be reduced accordingly, and mortality rates may remain at a high level long after the end of the war. Ghobarah, Huth, and Russett $(2003,2004)$ estimate that the number of deaths and disabilities in 1999 due to the lingering effects of civil wars that occurred between 1991 and 1997 is twice as large as the number of deaths and disabilities directly caused by civil wars that took place in 1999 .

These studies have highlighted the long lasting negative effects of civil war on survivor's health and life. So a special attention should be paid to survivors of conflicts, to reduce their post-conflict mortality and improve their health status, especially as survivors are the ones who bear the burden of reconstruction. Indeed, survivors are the labour force for the post-war recovery and the basis for the population growth. They are the recipients, and sometimes the supplier, of investments in physical and human capital. Therefore, an assessment of survivors' health is a key point for any policy of reconstruction and for the maintenance of peace in post-conflict. Neglecting the durable impacts of civil war on the survivors' health conditions may lead to inadequate reconstruction policies.

This paper offers a microeconomic analysis on the impact of the Mozambican civil war on the health of its survivors. Individual level information are obtained from the Mozambican Demographic and Health Survey (the fourth phase of DHS: DHS+: 2003). This database is particularly suited to this analysis since it provides a set of anthropometric indicator, among them I focus on the height for age z-score (HAZ) as a measure of long-term health. This indicator captures the durable consequences of illness and periods of malnutrition caused by armed conflict. This DHS representative household survey is combined with a new original database specially designed by the author to examine the spatial and temporal evolution of the Mozambican civil war. The empirical identification strategy follows the recent literature on this topic, such as the work of Bundervoet, Verwimp and Akresh (2009). 
This strategy exploits exogenous variations in the timing and duration of the war across the different Mozambican provinces. Using these variations, I distinguish which individuals had to face the conflict, at what age and for how long. However, the novelty of the paper is to focus on adult women rather than young children, as the previous literature on the subject has done. This allows to assess the impact of civil war on the whole human growth process, and not only during the infancy (i.e: the first stage of life).

The results of this paper corroborate those found in the recent literature. An exposure to the civil war in early stages of life induces a significantly lower height for age z-scores. Using the Infancy-Childhood-Puberty curves (ICP curves) ${ }^{7}$ this paper points out that this negative effect depends on the duration of civil war experienced on each growth stage. Furthermore, this study indicates that an additional month of civil war before a woman's birth has also a negative impact on her health, highlighting thus the importance of the prenatal conditions.

The paper proceeds as follows. Section 2 provides an overview of the political history of the Mozambican civil war. Section 3 describes the original database specifically design by the author on this conflict and the DHS data used for the analysis, and define the dependent variable. Section 4 explains the identification strategy for the empirical analysis. Section 5 presents the main results and tests their robustness. Section 6 concludes.

\section{2 - The Political History of Mozambican civil war ${ }^{8}$}

On June 25 1975, after a decade of struggles, Mozambique became independent. At that time, the first president of this new republic, Samora Machel, a member of the "Frente de Libertação de Moçambique” (FRELIMO), planned the establishment of a form of people's democracy in a single political party context, of which the program would be the "scientific socialism". ${ }^{9}$ But the first historical experience of independent Mozambique was a civil war between the FRELIMO and the "Resistência Nacional Moçambicana" (RENAMO), which lasted fifteen years, from 1977 to $1992 .^{10}$

\footnotetext{
${ }^{7}$ See the section 4 , for an explanation of ICP curves.

${ }^{8}$ A map of Mozambique is provide on annex 1

${ }^{9}$ Saul, John S. (ed). A Difficult Road: The Transition to Socialism in Mozambique, (New York: Monthly Review Press, 1985), p45 (quoting Samora Machel's Independence Day speech at Machava Stadium, 25 June 1975).

${ }^{10}$ Information provided by UCDP/PRIO Armed Conflict Dataset. Note that for Correlate of War (COW) the Mozambican civil war only took place from 1979 to 1992).
} 
The origins of the Mozambican civil war lie in two conflicts that took place in the $60 \mathrm{~s}$ and in the 70s: the Mozambican war of independence led by FRELIMO, and the war in Rhodesia.

Since 1964 FRELIMO led the war of independence of Mozambique, and in the 70s it succeeded to consolidate its positions near the Rhodesian border, in north-western Mozambique. At this time they welcomed and supplied a haven to the rebels of the "Zimbabwe African National Liberation Army" (ZANLA), group with an ideology close to them. From this haven the ZANLA could operate in Rhodesia. ${ }^{11}$

Indeed, in 1965, Rhodesia had unilaterally declared its independence, and it found itself confronted with internal Zimbabwean resistance, mainly formed by "Zimbabwe African National Union" (ZANU) and its armed wing the ZANLA. In response to the attacks of the ZANLA, Rhodesia began to form a first counter-insurgency unit, which also launched its first attacks against FRELIMO's infrastructures in Mozambican territory. ${ }^{12}$

Finally, when in 1975 FRELIMO came to power in Mozambique, it decided to comply with international requirements, closing its borders with Rhodesia. This decision was taken to deprive Rhodesia access to the "Beira Corridor" (Roads and railway line supplying Rhodesia connecting the port of the city of Beira to Rhodesia). Among other reprisals, Rhodesia decided to support the Mozambican dissidents opposed to FRELIMO. These dissidents were implanted in the Rhodesian counter-insurgency structures to form RENAMO and battle in Mozambique. ${ }^{13}$

This conflict can be divided into four periods:

- 1977-1980: RENAMO is an organization totally controlled by Rhodesia and it has launched the first attacks on Mozambican soil. These attacks took place mainly in central Mozambique near the border with Rhodesia, and spread gradually towards the south. At that time, RENAMO, which included a heterogeneous group of opponents at

\footnotetext{
${ }^{11}$ Ian Smith, The Great Betrayal, (London: Blake, 1997), p159.

${ }^{12}$ Stiff, Peter, The Silent War: South African Recce Operations 1969-1994, (Alberton: Galago, 1999), p88

${ }^{13}$ Robinson, David Alexander, Curse on the Land: A History of the Mozambican Civil War, (2006) PhD dissertation at School of Humanities The University of Western Australia
} 
the Mozambican government, targeted camps of ZANLA in the Rhodesian counterinsurgency operations and the infrastructures of FRELIMO. ${ }^{14}$

- 1980-1986: Following the independence of Zimbabwe, RENAMO lost the support of Rhodesia. But South Africa, willing to destabilize Mozambique, becomes the new support of RENAMO. The latter really started to settle down in Mozambique. ${ }^{15}$ The fighting intensified, first in the south (especially during the RENAMO's offensive towards Maputo 1982-83), and then in the north (with the FRELIMO's offensive that led to the downfall of the RENAMO's base of Gorongosa in the central province of Inhambane in 1985, and with the RENAMO's mean offensive in the province of Zambezia, in 1986-87). ${ }^{16}$

- 1987-1990: Period of high violence perpetuated by RENAMO against civilians, especially in the south ${ }^{17}$, despite the decline of South Africa's support. Indeed, in 1989, South Africa began to change its opinion on the best strategy to the Mozambique. In fact, the continuation of a conflict on its borders proved to be an important source of inconvenience (e.g. illegal influx of refugees). ${ }^{18}$

- 1990-1992: Period of negotiations during the Rome talks, which led to the resolution of the conflict on October 4, 1992. ${ }^{19}$ However, during this period, fighting continued in most provinces.

\footnotetext{
14 - Serapião, Luis B. "Mozambique's National Interest in the Regional Conflict of Southern Africa",Conflict, Vol 9, No 4, 1990, pp341-356. - Ian Smith, The Great Betrayal, (London: Blake, 1997), p184.

15 - Davies, Robert. "The SADF's Covert War Against Mozambique", in Jacklyn Cock and Laurie Nathan (eds), War and Society: The Militarisation of South Africa, (Cape Town: David Philip, 1989), pp104-105 - Cabrita, João M. Mozambique: The Tortuous Road to Democracy, (Basingstroke: Palgrave, 2000). p181 ${ }^{16}$ Cabrita, João M. Mozambique: The Tortuous Road to Democracy, (Basingstroke: Palgrave, 2000), 248.

${ }^{17}$ Robinson, David Alexander, Curse on the Land: A History of the Mozambican Civil War, (2006) PhD dissertation at School of Humanities The University of Western Australia, p270

${ }^{18}$ South African Foreign Affairs Archives "Staatkundlge Komitee: Voorgestelde Wysings Tov Strategie NR 19: Mosambiek", pp5-6.

19 - Vines, Alex. RENAMO: From Terrorism to Democracy in Mozambique? (London: James Currey, 1996).p12 - Saul, John S., "Inside from the Outside? The Roots and Resolution of Mozambique's Un/Civil War", in Taisier M. Ali and Robert O. Matthews (eds), Civil Wars in Africa: Roots and Resolution, (McGill-Queen's University Press: Montreal, 1999). p136.
} 
This civil war was long and brutal. One hundred thousand Mozambicans were killed directly by the war and nearly one million perished by its indirect consequences, such as starvation and lack or disruption of health services. ${ }^{20}$ Moreover, we must take into account the consequences of RENAMO's military strategy, based on kidnapping, looting and mutilation against the civilian population $^{21}$, and the enrollment of child soldiers. ${ }^{22}$

\section{3 - Data and measurement}

\section{1 - Spatial and temporal evolution of Mozambican civil war: an original database.}

In order to assess the impact of civil war in Mozambique, a spatial and temporal approach of the conflict is chosen. The objective is to take into account the heterogeneity existing between Mozambican provinces. Indeed, considering that a country can sink homogeneously into civil war would be inappropriate. The reality of a conflict within a country is much more complex. Some provinces experience the conflict from the beginning and others some years later, so some endure several consecutive years of violence, while others ones experience the consequences of the war for a short term or intermittently. Finally, each province can suffer different intensity of violence.

The description of the spatial and temporal evolution of Mozambican civil war, takes as a basis the historical research undergone by Alexander (2006). ${ }^{23}$ As the author states, the objective of his study is to present a detailed account of the political and military history of the civil war in Mozambique, based on a wide range of sources. Among these sources we can cite: RENAMO's internal documents, South African Foreign Affairs Archives, Malawian National Archives, various documents collected from the private archive of Dr Colin Darch (University of Cape Town), books and journal articles and newspapers/periodicals articles .... From this study, all the violent events that were recounted (like attacks or skirmishes ...), as well as events related to military strategies or movement recorded are identified to construct our database. Then, to the extent possible, I tried to crosscheck the collected information with

\footnotetext{
${ }^{20}$ Gersony, Robert. Summary of Mozambican Refugee Accounts of Principally Conflict-Related Experience in Mozambique, (Washington D.C.: Bureau for Refugee Programs, US Department of State, April 1988).p41

${ }^{21}$ Wilson, Ken. "Cults of Violence and Counter-Violence in Mozambique", Journal of Southern African Studies, Vol 18, No 3, September 1992, pp527-82. p531.

${ }^{22}$ Hanlon, Joseph. "Are Donors to Mozambique Promoting Corruption?", Paper submitted to the conference 'Towards a New Political Economy of Development', Sheffield 3-4 July 2002. pp369-372.

${ }^{23}$ Robinson, David Alexander, Curse on the Land: A History of the Mozambican Civil War, (2006) PhD dissertation at School of Humanities The University of Western Australia
} 
the presentation of the conflict, proposed in the book of Alex Vines (1991) ${ }^{24}$ and in the book of Michel Cahen (1994). ${ }^{25}$

Using this methodology I identified 1153 attacks, on which must be added 251 sabotages and other military operations summed in 901 events dated by year and by month (one single event can includes a set of attacks or sabotages). Then each of these 901 events war located in the 10 Mozambican provinces ${ }^{26}$. For the province of Maputo, I isolated the events which occurred in the heart of the capital Maputo City, from those which occurred in Maputo Province. Finally, for 606 of these events, it was possible to determine the location at the district level. The unlocalized events at this level are those for which a doubt remained in location or those for which information on the geographical location of the occurrence of the event were too vague.

As mentioned above, approaching the conflict both from a temporal and a spatial point of view highlights the heterogeneity between Mozambican provinces in their experience of the conflict. Indeed some provinces entered later into war than other ones and all the provinces could not have the same conflict end date.

To determine the conflict starting and ending date, for each province, I use a specific approach. Regarding the determination of the conflict start date, I have chosen not to select the date of the first event collected and located in each province. Indeed, the date of this first event rarely reflects the province entry into the war. It is clear that whatever the event (most often it is an ambush or sabotage), it is a local event and does not determine the entry in conflict for any provinces. This is the reason that led us to select, for each province, an event which clearly indicates that the province has gone into the civil war, and I take this date as the beginning of the war for this province. This type of events is necessarily the one that will allow us to conclude that a major part of province's territory suffers the consequences of the conflict.

For provinces for which I have the date of establishment of RENAMO (implantation of bases or headquarters), I selected this date as the date of entry to the war. This was the case

\footnotetext{
${ }^{24}$ Vines, Alex. RENAMO: Terrorism in Mozambique, (London: James Currey, 1991).

${ }^{25}$ Cahen, Michel. "Les Bandits. Un historien au Mozambique, 1994", Paris, Publications du Centre culturel Calouste Gulbenkian, juillet 2002, 354 p, ISBN : 972-8462-28-X,

${ }^{26}$ Localisation data obtained from www.maplandia.com.
} 
for the provinces of Cabo Delgado, Inhambane, Nampula, Sofala, Zambezia, Niassa and Maputo. The choice of this type of event is justified by the fact that it seems logical that the establishment of RENAMO occurs only in an area sufficiently under his control; and that this will give rise to future attacks in the province, from this military position. We must note that the case of Maputo Province is unusual because the conflict starting date chosen is the date of the great RENAMO's offensive in this region (1982), because it is from this event that RENAMO began to be active in the province.

For provinces for which I have not gathered an event indicating the establishment of RENAMO, another event has been selected to determine the date of entry into the war. In this case, the conflict start date is chosen as the date on which FRELIMO has placed the province under military command. The underlying assumption is that a province under such a command is a province clearly involved in a civil war context. This was the case in the provinces of Gaza, Manica and Tete. For the particular case of Manica province where the event indicating the establishment of RENAMO is dated in November 1978, but it was only in 1979 that RENAMO's military operations reached a significant scale, leading FRELIMO to place the province under military command, therefore, 1979 was the date selected to indicate Manica' entry into the war.

Finally, to determine the ending date of the conflict, the date of the last event collected and located in each province is chosen.

In addition, in order to avoid complication induced by the situation of the provinces that had a year in which there was no event collected, this discontinuity is ignored. Consequently, each province has a single conflict starting date and a single conflict ending date.

\section{2 - The Demographic and Health Survey database.}

In order to investigate the health's consequences of the civil war, the above database on the Mozambican conflict is merged with a DHS representative household survey. Initiated by the U.S Agency for International Development (USAID), the Demographic and Health Surveys (DHS) project provides, since the lasts 25 years, data on the population in developing countries. The DHS are based on representative samples of households, and all of these 
surveys use standardized households and women's questionnaires. Thereby, every five years, the DHS program collect data on nutrition and health of women and children, among which it is incorporated a set of anthropometric measures. As mentioned by Moradi and Baten (2005), training and equipment for height measurements followed WHO guidelines, using measuring boards with a headpiece ${ }^{27}$, and heights were recorded to the nearest millimetre.

In this article Mozambican' data collected during the fourth phase DHS + (DHS IV: 2003) are used. Table 1 Column 1 presents broken down by Mozambican province, the DHS roster (number of individuals in the sample). This phase of the DHS program has the advantage of having widespread recording anthropometric measure (body height and weight) for every child under 5 years and also for their mothers and for all women aged between 15 to 49 years old and present in the household during the interview (which was not the case in the previous phases). Only men were not measured. Hence, the DHS database provides a set of anthropometric data of high quality for 12144 eligible women ${ }^{28}$. This set of anthropometric data includes three indicators calculated in standard deviation: the height for age z-score (HAZ), the weight for age z-score (WAZ), and the weight for height z-score (WHZ). All of these allow to assess the nutritional status of measured individuals. This household survey data is merged with the data on the timing and the location of Mozambican civil war presented in the preceding section, and I focus on survivor' $\mathrm{HAZ}^{29}$, in order to examine the impact of this war on their health status.

The use of anthropometric data as a measure of health outcome has several advantages. The height and the weight of an individual are a non-estimated data, but easily measurable with a high degree of precision. Furthermore, these data are specific to an individual, in comparison to calculated averages for household members which do not take into account the possible intra-household bias. Finally, as recognized by international organizations specialized in health (WHO, NCHS, etc.), the presentation of anthropometric measures in terms of z-score is the best strategy in comparison to other means (e.g.: the median percentage, percentile, etc.), in particularly because a fixed deviation of z-score represents a fixed difference in height or in weight.

\footnotetext{
${ }^{27}$ See also (Loaiza, 1997).

28 Table 1, Column 2 indicates that, among these 12144 eligible women, only for 11946 of them DHS have mentioned the province were their living.

${ }^{29}$ Definition and formula are on annex 2
} 
Finally, the choice to focus on the HAZ as a dependent variable, instead of other anthropometric indicators, is due to the fact that it is the best indicator to capture the longterm effects on the health generated by a phenomenon that has occurred in the individuals' history. Indeed, even if the nutritional status of an individual is evaluated through various anthropometric indicators, only the HAZ is the indicator of chronic under-nutrition, which does not depend on the date on which it is collected, unlike the weight and the $\mathrm{WAZ}^{30}$. The HAZ is thus a long-term measure of under-nourishment translated into stunted growth at a given age of physical growth process, and into a smaller adult height. But the HAZ and the stature should not be only regarded as a proxy of nutritional status. Indeed, the adult height is the sum of increases in stature that occurred during the entire process of body growth. These increases in stature are positively affected by the quantity and the qualities of nutrients absorbed, and are negatively affected by diseases. More broadly, the HAZ reflect the biological component of human welfare (Komlos, (1999)). It illustrates how basic needs were satisfied during the first years of life.

\section{4 - Econometric Analysis}

\section{1 - Preliminary observations.}

As mentioned previously, the purpose of this paper is to estimate the impact of civil war on survivors' health, using an anthropometric indicator to capture the long-term effects: the height-for-age z-score (HAZ). Table 1, Column 3, shows broken down by province, the average $\mathrm{HAZ}$ for measured women. We note that the average HAZ of women in Mozambique is -1.308 , meaning that an average woman in Mozambique has a height-for-age that is 1.308 standard deviations lower than an average reference woman. There are variations across provinces, with an average HAZ varying from -1.753 in Cabo Delgado to -0.79 in Maputo City (the capital of Mozambique). Furthermore, women in rural Mozambique have an average HAZ lower than women in urban localisations.

\footnotetext{
${ }^{30}$ Regarding the WHZ, this index combines weight and height, so it does not allow concluding whereas it is due to a long-run dietary deficiency or to a concomitant dietary with the date of the measurement.
} 
Table1: Descriptive statistics and preliminary observations

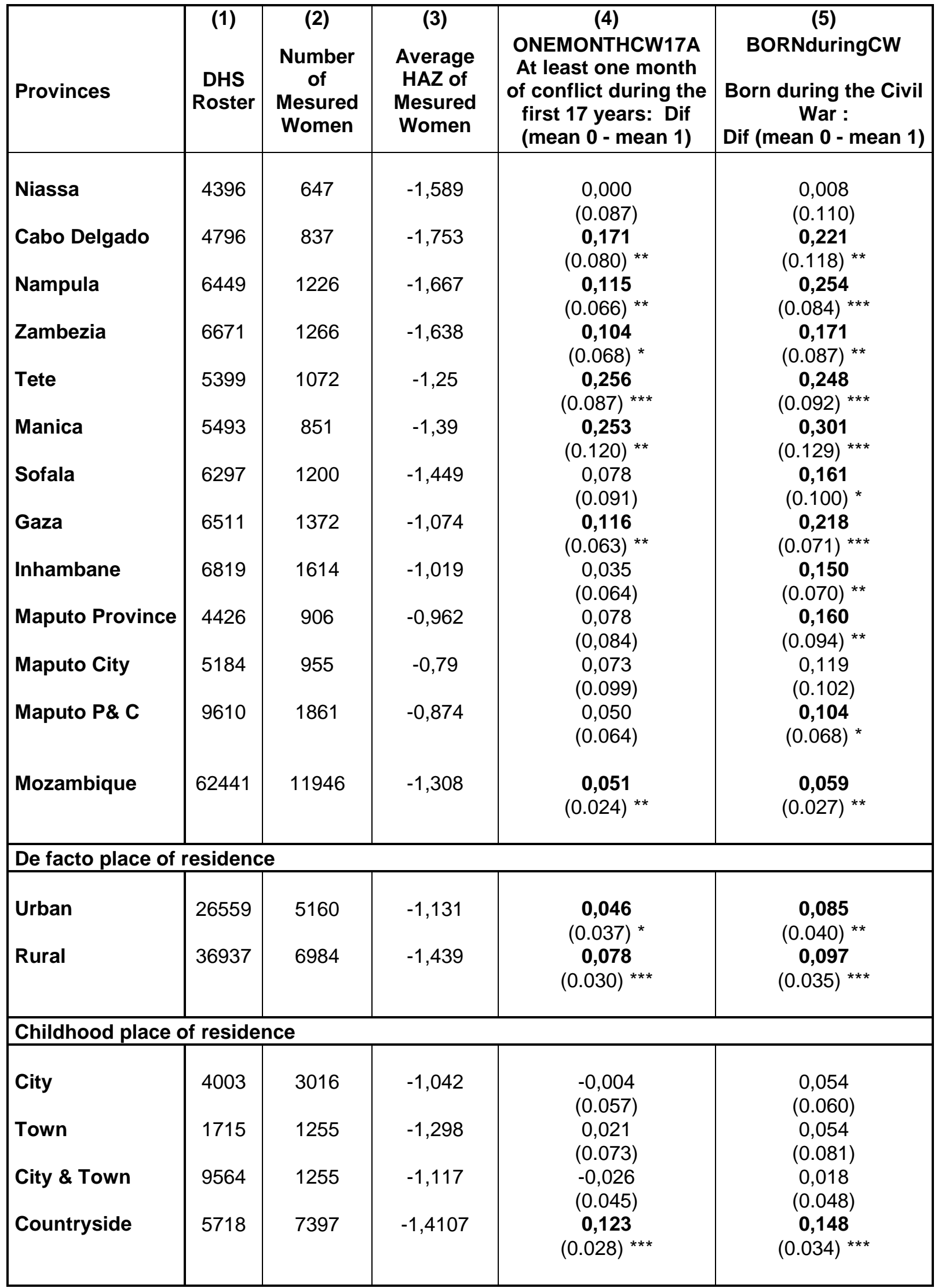


Then, to construct the conflict exposure variables, I use information given by the timing database of the Mozambican conflict, which specify the period during which a province has been exposed to the civil war. The conflict dates of each province are cross with the place of residence and the age of interviewed women, collected in the DHS + , to determine at what age and for how many times these women have experienced the war.

Our first conflict exposure variable is a dummy variable: ONEMONTHCW17A, which is coded 1 if a woman has been exposed at least 1 month to the civil war during her first seventeen years of life, and coded 0 otherwise. The age of seventeen years is chosen because a consensus indicates that this is the age at which women's body growth ends (Karlberg and al (2003)). Table 1, Column 4 presents results of mean comparison tests, whether ONEMONTHCW17A equals 1 or 0 . For every Mozambican province the difference in average HAZ between women exposed (ONEMONTHCW17A = 1) and not exposed $($ ONEMONTHCW17A $=0)$ is positive. This means that on average women exposed to the civil war in their early years of life have an HAZ lower than those not exposed. For most of the provinces, this positive difference is at least statistically significant at ten percent level. At the country level, this difference is evaluated at 0,051 and it is statistically significant at five percent level and this difference is larger in rural Mozambique $(0,078)$.

Our second conflict exposure variable is a dummy named BORNduringCW, which is coded 1 if a woman was born during the civil war (i.e. she spent her first month of life in a conflict area), and coded 0 if she did not have spend any month in war during her first seventeen years. In other words: BORNduringCW $=1$ is a subset of the ONEMONTHCW17A $=1$ set and BORNduringCW $=0$ corresponds to the same population of ONEMONTHCW17A $=0$. The aim of this approach is to consider the case of women who were born during the conflict. These are not necessarily those who suffered from all the duration of the civil war (as they may be born in the last month of the conflict, and therefore spent only one month in war). However, being born during a conflict it is a particularly case for many reasons. Among them, we note the fact that pregnancy which has preceded a birth, that took place during the civil war, was also held during the conflict, and it is possible that the war has an impact on prenatal health of individuals through the mother's health during pregnancy. 
Column 5 in Table 1 indicates the result of mean comparison tests, whether BORNduringCW equals 1 or 0 . Considering all the country, the difference in average HAZ between women born during the civil war $(\mathrm{BORNduringCW}=1$ ) and women who did not suffer any month of war before seventeen years of age (BORNduringCW $=0)$, is positive. This means that on average women born during the Mozambican conflict have a HAZ lower than the women not exposed to the conflict during their physical growth process. Furthermore, the differences found through BORNduringCW are larger than the differences found through ONEMONTHCW17A in almost province. This means that on average women born during the civil war have a HAZ lower than women exposed at the civil war in their early years of life.

From these preliminary observations, exposure to civil war seems to be negatively correlated with the long-run health, reflected by a smaller HAZ for women exposed to the conflict during their first years of life. Furthermore, this correlation seems to be influenced by the woman's age of entry in the war. Finally, when observing the results of mean comparison tests, by province, we can see that there are variations among the provinces (Columns 4 and 5). A possible explanation for these variations is the differences in number of years of war experienced by these different provinces. This leads us to think that the duration of conflict may have an influence on the negative correlation between war and long run health.

\section{2 - Identification and Econometric Specification}

We thus can infer the following hypotheses:

H1: The civil war has a durable negative impact on the survivors' health.

H2: This negative impact is influenced by the age of entry into the civil war and the number of years spent in conflict.

From H1, we can set the following relationship:

$$
\mathrm{HAZ}_{(\mathrm{o})}=\mathrm{HAZ}_{(\mathrm{n})}-\beta_{(\mathrm{cw})}(\text { Civil War })
$$


Where $\operatorname{HAZ}_{(\mathrm{o})}$ is the observed height for age z-score measured by DHS, $\beta_{(\mathrm{cw})}($ Civil War) is the health effect of civil war, and $\mathrm{HAZ}_{(\mathrm{n})}$ reflect the natural height for age $\mathrm{z}$-score (that is the HAZ that an adult should have without a civil war). This latter is a function of a set of determinants: Ethnicity, childhood place of residence, region of residence and other variables not observable in this case. Among them the most important is the height of the parents. Indeed the height of the parents influences the height of their children; unfortunately DHS does not provide the height for the parents of measured women. However this point is not problematic for this study, because the height of the parents does not influence the effect of civil war.

The emerging consensus from the literature on the link between ethnicity and height seems to show a very low impact of ethnicity. Anthropometric surveys have found that the differences in term of height between socio-economic elites and the poor population of the same ethnicity are more important then the differences observed between elites of different ethnic groups (Habicht and al, 1974). Moreover, different ethnic groups reach the same average adult height when their environment is maintained optimal for their physical growth (Eveleth and Tranner, 1990). Also the length at birth is fairly similar between different ethnic groups (Martorell and Habicht 1986). In other words, this denotes the primacy of the influence of environmental conditions on the ethnic influence. However, it is possible that ethnicity influences the nutritional practice, which may cause a correlation between adult height and ethnic groups. Consequently, all presented specifications include 28 dummies for the individual language spoken, which is a proxy for ethnic-specific influences in order to take into account the possible influence of a specific nutritional practice.

As mentioned above, the literature indicates that the environment plays an important role in the process of human growth. To capture this influence, I use two variables: the childhood place of residence (decomposed into city, town, and country side) and the region of residence. The childhood place of residence captures all effects induced by environmental differences existing between urban areas and non-urbanized areas (e.g. access to health and sanitary infrastructures). Studies have provided evidence that growth deficits are larger for infants living in peri-urban areas than in urban areas, and the greatest deficits are found in rural areas (Jalil and al., (1993), and Hagekull and al., (1993)). The 11 regional dummies are used to capture the differences between provinces (e.g. in terms of type of agriculture and stockbreeding, or in terms of supply of public health services). Finally, we can also regard the 
childhood place of residence and the region of residence as proxies for household wealth (Haddad and Hoddinott (1994), and Garrett and Ruel (1999)) or for parental education Glewwe (1999) and Chen and Li (2009), which also have an influence on the height of children. Indeed living in a place urbanized or not is correlated wealth and education.

To sum up, all specifications presented in this paper include the following set of control variables: ethno-linguistic membership, province fixed effects, and childhood place of residence. We can set the following relationship:

$$
\mathrm{HAZ}_{(\mathrm{n})}=\mathrm{f}(\text { Ethnicity, Childhood place of residence, Region of residence })+\varepsilon
$$

Now focusing on the first part of $\mathrm{H} 2$ hypothesis, we investigate how the age of entry in the civil war influences the effect of the conflict on health

From the Table 1 we saw that the negative coefficient of correlation between civil war and health is larger for women who have experienced conflict during their first year of life. As a preliminary analysis, I examine whether negative correlation remains when adding furthers controls. The specifications considered are the following:

$$
\mathrm{HAZ}_{(\mathrm{o}) \mathrm{ijt}}=\beta_{0}+\beta_{1}\left(\mathrm{Z}_{\mathrm{i}}\right) \quad+\beta_{2}(\mathrm{ONEMONTHCW17A})_{\mathrm{jt}}+\varepsilon_{\mathrm{ijt}}
$$

And :

$$
\begin{aligned}
\mathrm{HAZ}_{(\mathrm{o}) \mathrm{ijt}=} \beta_{0}+\beta_{1}\left(\mathrm{Z}_{\mathrm{i}}\right) \quad & +\beta_{2}(\text { ONEMONTHCWother17A })_{\mathrm{jt}} \\
& +\beta_{3}(\text { BORNduringCW })_{\mathrm{jt}}+\varepsilon_{\mathrm{ijt}}
\end{aligned}
$$

Where, $\mathrm{HAZ}_{(\mathrm{o}) \mathrm{jit}}$ is the outcome of interest for an individual $i$, in a province $j$, born at the date $t$, and (ONEMONTHCW17A) $)_{\mathrm{jt}}$ is defined in the same way as previously, $(\mathrm{BORNduringCW})_{\mathrm{jt}}$ is a dummy variable coded 1 if a woman was born during the civil war and coded 0 otherwise, and (ONEMONTHCWother17A) $)_{\mathrm{jt}}$ is coded similarly at ONEMONTHCWother17A) $)_{\mathrm{jt}}$ the only difference is that women born during the civil war are coded 0 and $(Z)$ is the set of control variables presented in equation (2).

Table 2 presents the regression results for Equations (a) and (b). Results in Column 1 show a negative impact of the ONEMONTHCW17A. The women exposed to the war at least 
one month during her first seventeen years have a height for age z-score 0.13 standard deviations lower than non-exposed women, this deterioration is statistically significant at the one percent level. Column 2, present a focus on the case of women born during the civil war. These women have a height for age z-score 0.23 standard deviations lower than non-exposed women; this is also statistically significant at one percent.

This result corroborates the observations provided by the Table 1 . The estimated effect of civil war is larger for women who have passed their first year of life in a region affected by the conflict than for women who have suffered the war for later ages. As a consequence, it seems that a negative correlation exists between age of entry in the war and the negative effect of civil war on health. Graphically this relationship could be drawn as follows:

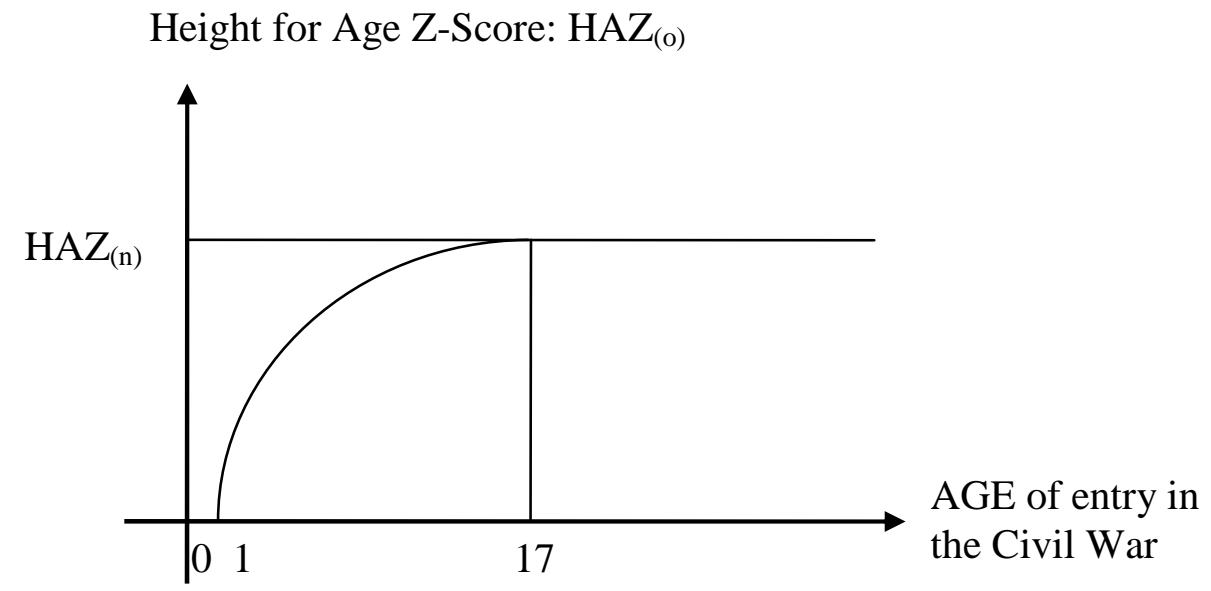

Figure 1: Height for Age z-score in function of the age of entry in the civil war.

In order to estimate this relationship, I employ this specification:

$$
\operatorname{HAZ}_{(\mathrm{o}) \mathrm{ijt}}=\beta_{0}+\beta_{1}(\mathrm{Z})_{\mathrm{i}} \quad+\beta 2(\text { LNAGEinCIVILWAR })_{\mathrm{jt}}+\varepsilon_{\mathrm{ijt}}
$$

Where, LNAGEinCIVILWAR is the logarithm of the age of entry in the civil war. ${ }^{31}$

\footnotetext{
${ }^{31}$ When a woman born during the conflict, this means that, she has passed her first month of life in the civil war, thus this variable take the value of 1 , and for the other women this variable take the value of the months of life at which they entered in the civil war.
} 
In table 2, column 3 indicates the OLS regression results for all measured women. Women aged more than 17 years old (i.e.: more than 204 month of life), when exposed to conflict, are considered as being 17 (204 month) in the OLS regression results presented in column 4. The value of 17 (204 month) is used for their age, on the assumption that women are fully grown by the age of 17 . The purpose of this restriction is to estimate the specification (c) for women whose physical growth is likely to be influenced by civil war. The coefficients for the logarithms of age of entry in the civil war, presented in column 3 and 4 are positive and significant at 1 percent level. The difference between these two coefficients is not statistically significant. These results indicate a positive causality between the age of entry into the civil war and the height for age $\mathrm{z}$-score. In other words, that is interpreted as evidence that the negative effect of civil war on health is influenced by the age of entry in the war. The negative impact of conflict is all the more important as the age entry in the war is young.

Table 2: Age influence on women's height for age z-scores

\begin{tabular}{|c|c|c|c|c|}
\hline $\begin{array}{l}\text { Dependent variable: Women's Height for } \\
\text { Age Z-Score (HAZ) }\end{array}$ & 1 & 2 & 3 & 4 \\
\hline $\begin{array}{l}\text { Women with at least } 1 \text { month of civil war } \\
\text { experienced during her first seventeen } \\
\text { years (ONEMONTHCW17A) }\end{array}$ & $\begin{array}{l}-0.13629 \\
(0.02008)^{\star * *}\end{array}$ & & & \\
\hline $\begin{array}{l}\text { Women with at least } 1 \text { month of civil war } \\
\text { experienced during her first seventeen } \\
\text { years and born before the civil war } \\
\text { (ONEMONTHCWother17A) }\end{array}$ & & $\begin{array}{l}-0.08831 \\
(0.02653)^{* * *}\end{array}$ & & \\
\hline $\begin{array}{l}\text { Women born during the civil war } \\
\text { (BORNduringCW) }\end{array}$ & & $\begin{array}{l}-0.23094 \\
(0.01720)^{\star * \star}\end{array}$ & & \\
\hline $\begin{array}{l}\text { Log of age of entry in the civil war } \\
\text { (LNAGEinCIVILWAR) }\end{array}$ & & & $\begin{array}{c}0.03939 \\
(0.00285)^{* * *}\end{array}$ & $\begin{array}{c}0.03998 \\
(0.00293)^{* * *}\end{array}$ \\
\hline Constant & $\begin{array}{c}-1.24217 \\
(0.08102)^{\star * *}\end{array}$ & $\begin{array}{c}-1.21711 \\
(0.08051)^{\star \star \star}\end{array}$ & $\begin{array}{c}-1.44775 \\
(0.07768)^{\star * \star}\end{array}$ & $\begin{array}{c}-1.44826 \\
(0.07786)^{\star * *}\end{array}$ \\
\hline $\begin{array}{l}\text { Observations } \\
\text { R-squared }\end{array}$ & $\begin{array}{l}11467 \\
0.0980\end{array}$ & $\begin{array}{l}11467 \\
0.1015\end{array}$ & $\begin{array}{l}11467 \\
0.1024\end{array}$ & $\begin{array}{l}11467 \\
0.1023\end{array}$ \\
\hline
\end{tabular}

Note: Robust standard errors in parentheses and clustered at the province level. * significant at $10 \%$; ** significant at $5 \%$; ${ }^{* * *}$ significant at $1 \%$. All provinces are included in the regressions. All regressions include Ethno-linguistic dummies, Childhood place of residence fixed effect, and province dummies.

For the rest of this study, an important point must be clarified. Isolating and estimating the influence of the number of years passed into the civil war on our dependent variables: height for age z-score is clearly impossible. Indeed we can not dissociate the influence of time 
spent into the civil war, from the influence of the age at which individuals have endured this duration on conflict. To illustrate this point, we can consider this example: the case of someone who spent fourteen years in a province affected by war, but with an age of entry in the war of thirty; it is certain that at this age his physical growth is complete, thus its height for age z-score will not be affected by civil war. Therefore for the whole population, an estimation of the influence of the number of years passed in the civil war without considering the age at which individuals experienced this duration of conflict will inevitably be biased.

A possible solution to take into account this bias consists to restrict the study sample to individuals who suffered war only during their physical growth period. However this strategy is equivalent to take the effect of the age into account and for this, there is a more optimal strategy.

As discussed above, the influence of the duration of civil war can not be taken into account without the influence of the age at which individuals experienced this duration of conflict. To estimate this joint influence, several strategies exist. All of them can be summed up within the same idea: define the population by using a criterion of age. As a consequence, the important point which must be taken into account is the choice of these subdivisions. The objective is to select a criterion, simple, non-arbitrary and efficient in terms of estimating the effect of civil war.

The medical literature studying body growth proposes a concept to meet this objective, and which is schematised by the curves Infancy - Childhood - Puberty (Karlberg J, (1987), (1989), and Karlberg J and al. (1976), (1987a), (1987b)). The I.C.P curves are based on a concept that takes two types of information into account; on the one hand, the fact that factors influencing human growth did not even balance throughout the growth process. On the other hand the fact that the dynamics of physical growth also varies during the growth process. In matching these two information, it is possible to identify three successive periods, describing the whole human growth process, and advising on the factors that could cause a downturn in growth. 
These three periods are defined as follows:

- Infancy (from the birth to 2 years): It is a phase of fast growth, mainly influenced by nutrition, and secondarily by Growth hormone (GH).

- Childhood (from 2 years to Puberty): It is a phase characterized by steady growth, influenced primarily by GH and secondarily by nutrition.

- Puberty (for girls, the onset is on average between 9 and 11 years, and the end is at sixteen years): During this phase, growth accelerates. The determining factors are, by order of importance: sex steroids, growth hormone, and finally nutrition.

From these three phases of human growth, three variables can be defined, in order to estimate the joint influence of the duration (here: the number of months) spent in conflict and of the age at which individuals experienced this duration of conflict.

DURATIONofCW_Infancy, is a variable that captures the impact of the duration of the civil war which was occurred during the infancy stage of the human growth process. As mentioned previously the infancy stage takes into account the first two years of life (i.e.: the first twenty-four month). Therefore, for all women who have suffered the civil war during their infancy, this variable takes values of the number of months of conflict they faced during this stage of the growth process.

DURATIONofCW_Childhood, is a variable that captures the impact of the duration of the civil war which was occurred during the childhood stage of growth process. The Childhood stages start after two years of age and finish over ten years of age (i.e.: this stage start after the twenty-fourth month and finish over the hundred and thirty-second month of life). This variable takes values of the number of month of conflict they faced during this stage of growth process.

DURATIONofCW_Puberty, is a variable that captures the impact of the duration of the civil war which was occurred during the puberty stage of growth process. The puberty stages start after ten years of age and finish over seventeen years of age. Over ten years of age (i.e.: the thirty-second month of life) is selected to mark the end of childhood and early puberty. This corresponds to the average age of onset of puberty. Indeed, as we have already mentioned the beginning of puberty for women takes place between nine and eleven years of age. Thereby, for all women who have suffered the civil war during their puberty, this 
variable takes values of the number of months of conflict they faced during this stage of growth process.

A possible limitation of this decomposition is that women born during the civil war are not isolated, while we saw that they suffer more than other. Still using ICP curves, but in order to isolate the specific case of women born during the civil war, a new variable is defined. The specificity of women born during the civil war is that they do not only suffer from the number of experienced months of war but also from the compounded number of months of war prior to their birth. The disruption in the sanitary and health systems of the province that were caused by the civil war before their birth should be taken into account. Such disruption may have altered the health of the women who were born during the civil war through the health of their mothers and in particularly the mother's health status during pregnancy. Note on this point, that Almond and Mazumder (2005) identifies that foetal injuries compromise adult health. Therefore another variable must be defined to account for the influence of the number of months of conflict that occurred before the birth of a woman. The variable MONTHSofCWatBIRTH captures this influence, by taking the number of months of civil war that had gone on in the province until the woman's date of birth.

To sum up, the HAZ of a woman, depending on $\sum_{k=(I, C, P)} \beta_{\mathrm{k}}$ (DURATIONofCW_k) ${ }_{\mathrm{jt}}$, $\mathrm{Z}_{\mathrm{i}}$, and MONTHSofCWatBIRTH $)_{\mathrm{j} t}$, is described by the following specification:

$$
\begin{aligned}
\operatorname{HAZ}_{(\mathrm{o}) \mathrm{ijt}}=\beta_{0} & +\beta_{\mathrm{Z}}(\mathrm{Z})_{\mathrm{i}} \\
& +\sum_{k=(I, C, P)} \beta_{\mathrm{k}}(\text { DURATIONofCW_k })_{\mathrm{jt}} \\
& +\beta_{\mathrm{N}}(\text { MONTHSofCWatBIRTH })_{\mathrm{jt}}+\varepsilon_{\mathrm{ijt}}
\end{aligned}
$$

Where, $\sum_{k=(I, C, P)} \beta_{\mathrm{k}}(\text { DURATIONofCW_k })_{\mathrm{jt}}$ is the sum of the sets of components of human growth process defined above from the ICP curves, and $(\mathrm{Z})_{\mathrm{i}}$ the set of control variables presented in equation (2). 


\section{5 - Estimations results and robustness}

\section{1 - Results}

We have already said the height for age z-score is a long-term indicator of the health status. Furthermore, as defined by Moradi (2002), "final adult height is a function of conditions in youth, especially of the nutritional quality and quantity as well as the epidemiological environment, which the individuals have faced during their period of growth". Consequently, if civil war has an impact on health, (measured here as a lower HAZ), the influence of the war will be much larger when the stage of human growth is more sensitive to nutrient intakes. The brief description of the different stages of human growth, presented earlier, establishes some intuitions about the presumed results. Therefore, we expect that Infancy is the stage most impacted by civil war, because it is a stage during which growth is mainly influenced by nutrition. Due to the same reason, we can assume that the negative effect of the civil war is decreasing throughout the physical growth process.

Table 3 presents OLS regression results for equation (d). The dependent variable for each regression is the women's height for age z-score (HAZ) and each of them includes the following as controls: 28 Ethno-linguistic dummies, Childhood place of residence fixed effect, and 11 province dummies. Variables capturing the effect of civil war are defined above. For all regressions in Table 3, the identification strategy exploits the variation across all Mozambican provinces in terms of timing and duration of conflict and the related exposition of each woman to the civil war.

Column 1 shows the estimation results of the decomposition of the human growth process drawn by the ICP curves. A negative causal impact of the civil war on the women's long-run health is evidenced. This impact is attenuated according to the stage at which the duration of conflict is sustained. We show that an additional month of civil war exposure suffered during the infancy leads to a larger decrease in final height-for-age z-score than an additional month of civil war faced suffered during the other two stages of the human growth process. This result confirms the soundness of the decomposition of the human growth process using the ICP curves. 
Table 3: ICP decomposition of civil war influences on height for age z-scores

\begin{tabular}{|c|c|c|c|}
\hline $\begin{array}{l}\text { Dependent variable: Women's Height for Age } \\
\text { Z-Score (HAZ) }\end{array}$ & $\begin{array}{l}(1) \\
\text { OLS }\end{array}$ & $\begin{array}{l}(2) \\
\text { OLS }\end{array}$ & $\begin{array}{l}(3) \\
\text { OLS }\end{array}$ \\
\hline DURATIONofCW_Infancy_1_24 & $\begin{array}{l}-0.00749 \\
(0.00044)^{\star * \star}\end{array}$ & $\begin{array}{c}-0.00504 \\
(0.00142)^{\star * *}\end{array}$ & $\begin{array}{l}-0.00381 \\
(0.00168)^{\star *}\end{array}$ \\
\hline DURATIONofCW_Childhood_25_132 & $\begin{array}{c}-0.00088 \\
(0.00032)^{\star * \star}\end{array}$ & $\begin{array}{c}-0.00116 \\
(0.00024)^{\star \star \star}\end{array}$ & $\begin{array}{c}-0.00150 \\
(0.00029)^{\star \star \star}\end{array}$ \\
\hline DURATIONofCW_Puberty_133_204 & $\begin{array}{l}-0.00076 \\
(0.00042)^{*}\end{array}$ & $\begin{array}{l}-0.00074 \\
(0.00042)\end{array}$ & $\begin{array}{l}-0.00122 \\
(0.00040)^{\star *}\end{array}$ \\
\hline MONTHSofCWatBIRTH & & $\begin{array}{c}-0.00112 \\
(0.00056)^{* *}\end{array}$ & $\begin{array}{c}-0.00138 \\
(0.00059)^{* *}\end{array}$ \\
\hline Constant & $\begin{array}{c}-1.24368 \\
(0.07647)^{\star \star \star}\end{array}$ & $\begin{array}{c}-1.24305 \\
(0.07612)^{\star \star \star}\end{array}$ & $\begin{array}{c}-1.22611 \\
(0.11346)^{\star \star *}\end{array}$ \\
\hline $\begin{array}{l}\text { Observations } \\
\text { R-squared }\end{array}$ & $\begin{array}{c}11467 \\
0.10281\end{array}$ & $\begin{array}{c}11467 \\
0.10313\end{array}$ & $\begin{array}{c}6536 \\
0.10619\end{array}$ \\
\hline
\end{tabular}

Note: Robust standard errors in parentheses and clustered at the province level. * significant at $10 \%$; ${ }^{* *}$ significant at $5 \%$; ${ }^{* *}$ significant at $1 \%$. All provinces are included in the regressions. All regressions include Ethno-linguistic dummies, Childhood place of residence fixed effect, and province dummies.

Column 2 provides the results of the estimation for the specification (d) that introduces the variable MONTHSofCWatBIRTH together with the set of variables coming from the decomposition of the human growth process. This variable takes into account the influence of the number of months of civil war prior to birth in order to analyse the particular case of women born during the conflict. Indeed as previously explained, women born during the civil war are characterized by the fact that they do also suffer from the duration of war prior to their birth.

Firstly this result allows us to conclude that the inclusion of the variable MONTHSofCWatBIRTH, does not question the logic of ICP curves previously described. Indeed, the negative causal impact of the civil war on the women's long-run health still remains. The reduction in the magnitude of this effect, depending on the growth stage at which the duration of conflict is sustained, is similar to the previous results.

Secondly, we show that an additional month of civil war exposure during her infancy, of a woman reduces her final height-for-age z-score by 0.00504 standard deviations, while this effect is only a decrease of 0.00116 standard deviations for a woman exposed at the civil 
war during her childhood. ${ }^{32}$ Finally for a woman exposed to the civil war during her puberty this decrease is by 0.00074 . These results confirm the intuitions presented above: the stages of human growth which are most affected by civil war are those primarily influenced by nutrition. Furthermore these results are also consistent to the research of Martorell and Habicht (1986), that instructs us on the fact of the first two years of the life are decisive for growth.

Finally focusing on the variable MONTHSofCWatBIRTH we note that an additional month of civil war exposure after birth decreases final height-for-age z-score by 0.00112 standard deviations; which is substantially the same effect as the one found for an additional month of civil war sustained during the childhood. This result highlights the importance of pre-natal conditions for women born during the civil war and underlines the fact that these women are the ones who are the most negatively affected by the conflict.

Now we can calculate the total average decrease of the height-for-age z-score due to the Mozambican civil war. On average the cumulative effect of civil war is a decrease of 0,1532 standard deviation in the height-for-age z-score. Using the formula of HAZ given in Annex 2, we can present this variation in terms of centimeters lost in adulthood: $-1.0251 \mathrm{~cm}{ }^{33}$ This decrease in adult height must be considered in comparison to the secular trend in adult height (i.e.: the intergenerational increase in height). The literature on this topic tends to show that the secular trend in adult height is an increase by $1 \mathrm{~cm}$ per decade (Garn (1987), Hauspie al. (1997), and Eveleth and Tanner (1990)). Consequently if we consider that the average duration of conflict sustained by a woman is around 9 years (109 months), we can conclude that the Mozambican civil war has resulted in a reversal in the secular trend of adult height. We can therefore concur to Paul Collier's affirmation (2004), civil war is a "development in reverse".

Column 3 provides a robustness check of the specification (d) results. Several robustness tests can be performed, but the most important one is to take into account the possible internal migration that took place during the conflict period. Indeed, civil war induces migration of population, thus we must consider the fact that some people were able to escape from the violence perpetuated in their region, as it influences the duration of conflict

\footnotetext{
${ }^{32}$ These two results are statistically significant at one percent level.

${ }^{33}$ For a woman of 17 years age old (i.e.: 204 months): $\Delta$ height (in $\left.\mathrm{cm}\right)=\Delta H A Z * 6.6917$. With 6.6917 is the Standard deviation from the NCHS/FELS/CDC Reference Population for a women aged of 204 month.
} 
that they have suffered. This is problematic because the determination of the duration of war attributed is based on the women's region of birth. Consequently, internal migrations are a potential source of bias in our previous estimations. In order to take into account this phenomenon, the column 3 provides the results for the specification (d) estimation, but for a restricted sample of women who still live in the province where they were born. The results found with this restriction are still consistent with the results found in column 2 .

\section{2 - Robustness}

From the previous results the most relevant specification appears to be that of column 2, table 3 which is reintroduced in Table 4. Using this specification, we can test the robustness of the results. Two other biases may emerge. First, the results could depend on a certain region. Second, the choice made for the age of the puberty's onset may not be correct.

As far as the first bias is concerned, the province sample has been restricted, in order to control the robustness of the results previously provided. In column 4 all provinces are included, except the province of Niassa, while in column 5 it is the province of Gaza which is taken off the province sample. With this strategy, the province who suffered the shortest period of conflict is excluded from column 4, while the province who endured the longest period of war is excluded from column 5 . We see that estimation results are robust to these alternative sample specifications.

To address the issue of the potential second bias, columns 6 and 7 provide the estimation results for specification (d), with the same identification strategy used for results given in table 3, columns 2 and 3. The only difference is the age of the onset of puberty. For the columns 6 and 7, puberty has been set to begin at the end of the tenth year of life (i.e.: 120 months) while in columns 2 and 3 it has been set at over ten years of age (i.e.: 132 month of life). We note that the change in the timing of the puberty does not question the logic of ICP curves nor the results previously described. 
Table 4: Robustness specification of the ICP decomposition of civil war influences on height

\begin{tabular}{|c|c|c|c|c|c|}
\hline \multirow[b]{2}{*}{$\begin{array}{l}\text { Dependent variable: Women's Height } \\
\text { for Age Z-Score (HAZ) }\end{array}$} & \multicolumn{3}{|c|}{ for age Z-scores } & \multirow[b]{2}{*}{$\begin{array}{c}6 \\
\text { OLS }\end{array}$} & \multirow[b]{2}{*}{$\begin{array}{c}7 \\
\text { OLS }\end{array}$} \\
\hline & $\begin{array}{c}2 \\
\text { OLS }\end{array}$ & $\begin{array}{c}4 \\
\text { OLS } \\
\text { Without } \\
\text { Niassa } \\
\end{array}$ & $\begin{array}{c}5 \\
\text { OLS } \\
\text { Without } \\
\text { Gaza } \\
\end{array}$ & & \\
\hline DURATIONofCW_Infancy_1_24 & $\begin{array}{c}-0.00504 \\
(0.00142)^{* * *}\end{array}$ & $\begin{array}{c}-0.00478 \\
(0.00153)^{\star *}\end{array}$ & $\begin{array}{c}-0.00624 \\
(0.00109)^{\star \star *}\end{array}$ & & \\
\hline DURATIONofCW_Childhood_25_132 & $\begin{array}{c}-0.00116 \\
(0.00024)^{\star * *}\end{array}$ & $\begin{array}{c}-0.00116 \\
(0.00025)^{\star \star \star}\end{array}$ & $\begin{array}{c}-0.00131 \\
(0.00024)^{\star * *}\end{array}$ & & \\
\hline DURATIONofCW_Puberty_133_204 & $\begin{array}{l}-0.00074 \\
(0.00042)\end{array}$ & $\begin{array}{l}-0.00073 \\
(0.00044)\end{array}$ & $\begin{array}{c}-0.00112 \\
(0.00031)^{\star \star *}\end{array}$ & & \\
\hline MONTHSofCWatBIRTH & $\begin{array}{c}-0.00112 \\
(0.00056)^{*}\end{array}$ & $\begin{array}{c}-0.00123 \\
(0.00059)^{*}\end{array}$ & $\begin{array}{l}-0.00062 \\
(0.00044)\end{array}$ & & \\
\hline Constant & $\begin{array}{c}-1.24305 \\
(0.07612)^{\star \star \star}\end{array}$ & $\begin{array}{c}-1.29416 \\
(0.11908)^{\star \star \star}\end{array}$ & $\begin{array}{c}-1.24105 \\
(0.07864)^{\star \star \star}\end{array}$ & & \\
\hline DURATIONofCW_Infancy_1_24 & & & & $\begin{array}{c}-0.00492 \\
(0.00147)^{\star \star *}\end{array}$ & $\begin{array}{c}-0.00383 \\
(0.00177)^{*}\end{array}$ \\
\hline DURATIONofCW_Childhood_25_120 & & & & $\begin{array}{c}-0.00121 \\
(0.00023)^{\star \star \star}\end{array}$ & $\begin{array}{c}-0.00151 \\
(0.00030)^{\star \star *}\end{array}$ \\
\hline DURATIONofCW_Puberty_121_204 & & & & $\begin{array}{c}-0.00078 \\
(0.00041)^{\star}\end{array}$ & $\begin{array}{c}-0.00127 \\
(0.00038)^{\star * *}\end{array}$ \\
\hline MONTHSofCWatBIRTH & & & & $\begin{array}{c}-0.00113 \\
(0.00056)^{\star}\end{array}$ & $\begin{array}{c}-0.00138 \\
(0.00060)^{\star *}\end{array}$ \\
\hline Constant & & & & $\begin{array}{c}-1.24297 \\
(0.07619)^{\star \star \star}\end{array}$ & $\begin{array}{c}-1.22562 \\
(0.11355)^{\star * *}\end{array}$ \\
\hline Observations & 11467 & 10848 & 9915 & 11467 & 6536 \\
\hline R-squared & 0.10313 & 0.10292 & 0.10537 & 0.10313 & 0.10618 \\
\hline
\end{tabular}

Note: Robust standard errors in parentheses and clustered at the province level. ${ }^{*}$ significant at $10 \%$; ${ }^{* *}$ significant at $5 \%$; ${ }^{* *}$ significant at $1 \%$. All provinces are included in the regressions. All regressions include Ethno-linguistic dummies, Childhood place of residence fixed effect, and province dummies.

\section{6 - Conclusion}

The aim of this paper is to provide some answers to the following questions: how does civil war impact the survivors' health, to what extent and for how long? Answers to these issues are crucial for the conception and the implementation of assistance policies for survivors and for reconstruction policies during the post-war period.

To draw conclusions on these issues, the case of the Mozambican civil war has been analysed in this paper, using a new original database specifically designed by the author to examine the spatial and temporal evolutions of this conflict. The empirical strategy takes advantage of exogenous variations in the timing and duration of war across the different Mozambican provinces. In combining this information with a DHS representative household 
survey, such variations allow the identifications of individuals who were exposed to the conflict, at what age and for how long they had face it.

Focusing on the height for age z-score of adult women (an anthropometric indicator of long term health), a durable negative effect of the civil war on survivors' health is found. This impact is a function of the individual's age of entry into the conflict and the number of months spent in civil war. The paper identifies more specifically that women who were born during the conflict suffer more from the negative impact. They do also suffer from the duration of war prior to their birth. Indeed, the results point out that an additional month of civil war before birth has an impact on the height-for-age z-score, thereby highlighting the importance of pre-natal conditions for these women. Furthermore, such as established by Martorell and al. (1994), subjects who remain in a stunting environment have few or no catchup in growth later in life.

Moreover, the poor health status of Mozambican survivors, which is in itself a tragic consequence of the conflict, also induces other adverse effects in the long run. Indeed, as recent works have shown, the damaged health status (particularly the damage due to malnutrition during childhood) reduces the welfare (Behrman and Rosenzweig (2005)), diminishes the number of completed school grades (Alderman and al. (2006)), the post school productivity (Alderman and al. (2001)) and the labour productivity (Behrman (1993)), and finally induces less income (Bleakley (2007)).

All of these durable adverse effects have to be accounted for to take the measure of the considerable consequences that arise from a population's damaged health status due to armed conflict and therefore emphasize the importance of preventing civil wars. Furthermore, given that the effect of civil war on survivors' health is long-standing and accumulated throughout the years of war, an intervention to stop ongoing conflicts will always have an important benefit to the long-run welfare. 


\section{References}

Almond, D. and Mazumder, B. (2005). "The 1918 Influenza Pandemic and Subsequent Health Outcomes: An Analysis of SIPP Data". American Economic Review; May2005, Vol. 95 Issue 2, p258-262,

Arcand, J.L. and Djimeu Wouabe, E. (2009). "Households in a Time of War: Evidence for Angola"

Alderman, Harold, Jere Behrman, Victor Lavy, and Rekha Menon, 2001, "Child Health and School Enrollment: A Longitudinal Analysis." Journal of Human Resources 36(1):185205.

Alderman, Harold, John Hoddinott, and Bill Kinsey. 2006. "Long Term Consequences of Early Childhoud Malnutrition." Oxford Economic Papers 58(3):450-74.

Behrman, J. (1993), "The Economic Rationale for Investing in Nutrition in Developing Countries", World Development, 21 (11), pp. 1749-72.

Behrman, J. and Rosenzweig, M. "The Returns to Birth Weight", Review of Economics and Statistics, 2005, 86, pp. 586-601.

Blattman, C. and Annan, J (2007). "The Consequences of Child Soldiering." HiCN Working Paper, 22. Forthcoming in the Review of Economics and Statistics

Blattman, C and Miguel, E (2008). "Civil War." forthcoming in Journal of Economic Literature.

Bleakley, H. (2007), "Disease and Development: Evidence from Hookworm Eradication in the American South", Quarterly Journal of Economics, Feb. 2007, 122 (1), pp. 73-117.

Bundervoet, T., Verwimp, P. and Akresh, R., (2009). "Health and Civil War in Burundi." Journal of Human Resources, Vol. 44 Issue 2, p536-563

Brück, T. (1997), "Macroeconomic Effects of the War in Mozambique". Report to ODA.

E.V.K. FitzGerald and F. Stewart (eds), Queen Elizabeth House, Oxford.

Cabrita, João M. (2000). "Mozambique: The Tortuous Road to Democracy," (Basingstroke: Palgrave)

Cahen, M.(2002). "Les Bandits. Un historien au Mozambique, 1994", Paris, Publications du Centre culturel Calouste Gulbenkian, juillet 2002, 354 p, ISBN : 972-8462-28-X,

Chen Y, Li H. Mother's education and child health: Is there a nurturing effect? Journal of Health Economics. 2009;28(2):413-26.

Collier, P. (1999). "On the economic consequences of civil war." Oxford Economic Papers, 51, pp. 168-83. 
Collier, P. (2004), "Development and Conflict", mimeo, Centre for the Study of African Economies Centre for the Study of African Economies, Department of Economics, Oxford University, October 1st, 2004.

Collier, P. and Hoeffler, A. 1998. "On economic causes of civil war." Oxford Economic Papers, 50:4, pp. 563-73.

Collier, P. and Hoeffler, A. 2004. "Greed and Grievance in Civil War." Oxford Economic Papers, 56:4, pp. 563-95.

Collier, P., Hoeffler, A and Soderbom, M. (2004). "On the Duration of Civil War." Journal of Peace Research, 41:3, pp. 253.

Davis, D. and Kuritsky, J. (2002). "Violent conflict and its impact on health indicators in SubSaharan Africa, 1980 to 1997". Paper presented at the annual meeting of the International Studies Association, New Orleans, LA.

Davies, R. "The SADF's Covert War Against Mozambique", in Jacklyn Cock and Laurie Nathan (eds), War and Society: The Militarisation of South Africa, (Cape Town: David Philip, 1989), pp104-105

Elbadawi, I. and Sambanis, N (2000), "External Interventions and the Duration of Civil Wars", Policy Research Working Paper \# 2433, Development Research Group, The World Bank, Washington, D.C.

Eveleth, P. B. and J. M. Tanner (1990). Worldwide Variation in Human Growth. Cambridge: Cambridge University Press.

Fearon, J. and Laitin, D. (2003), "Ethnicity, Insurgency and Civil War", American Political Science Review 97 (1): 75-90.

Garn, S.M. (1987) "The Secular Trend in Size and Maturational Timing and Its Implications for Nutritional Assessment", J. Nutr. 117: 817-823.

Garrett JL, Ruel MT. Are Determinants of Rural and Urban Food Security and Nutritional Status Different? Some Insights from Mozambique. World Development. 1999;27(11):195575 .

Gersony, R. (1988) "Summary of Mozambican Refugee Accounts of Principally ConflictRelated Experience in Mozambique”, (Washington D.C.: Bureau for Refugee Programs, US Department of State, April 1988).p41

Ghobarah, H., Huth, P. and Russett, B. (2003). "Civil Wars Kill and Maim People_Long after the Shooting Stops.” American Political Science Review 97(2): 189-202.

Ghobarah, H., Huth, P.and Russett B. (2004) "The post-war public health effects of civil conflict". Soc Sci Med. 2004;59:869-884.

Glewwe P. Why Does Mother's Schooling Raise Child Health in Developing Countries?

Evidence from Morocco. The Journal of Human Resources. 1999;34(1):124-59 
Guha-Sapir, D. and Degomme, O. (2006), "Counting the Deaths in Darfur: estimating Mortality from Multiple Survey Data", Working Paper no. 15, Households in Conflict Network, Institute of Development Studies at the University of Sussex, Brighton

Gupta, Irani and Arup Mitra. 2004. "Economic Growth, Health and Poverty: An Exploratory Study for India." Development Policy Review, Volume 22, Number 2 (March, 2004), pp. 193206,

Habicht, J.-P., C. Yarbrough, R. Martorell, R. M. Malina and R. E. Klein (1974). Height and Weight Standards for Preschool Children: How Relevant Are Ethnic Differences? Lancet 303 (7858): 611-615.

Haddad L, Hoddinott J. Women's income and boy-girl anthropometric status in the Cote d'Ivoire. World Development. 1994;22(4):543-53.

Hanlon, J.( 2002.) “Are Donors to Mozambique Promoting Corruption?", Paper submitted to the conference 'Towards a New Political Economy of Development', Sheffield 3-4 July

Hagekull B, Nazir R, Jalil F \& Karlberg J, (1993): Early child health in Lahore, Pakistan. III. Maternal and family situation. Acta Paediatr. Scand, Suppl. 390, 27-37.

Hauspie R, Vercauteren M, Susanne C, (1997). "Secular changes in growth and maturation: an update". Acta Paediatr Suppl 1997, 423 : 20-27

Hoeffler, A. and Reynal-Querol, M. (2003), "Measuring the Costs of Conflict", mimeo, Oxford: Centre for the Studies of African Economies.

Jalil F, Lindblad BS, Hanson LÅ et al. (1993): Early child health in Lahore, Pakistan. I. Study design. Acta Paediatr. Scand., Suppl. 390, 3-16.

Justino,P. (2009). "The Impact of Armed Civil Conflict on Household Welfare and Policy Responses," Research Working Papers 12, MICROCON - A Micro Level Analysis of Violent Conflict.

Justino, P (2008). "Poverty and Violent Conflict: A Micro Level Perspective on the Causes and Duration of Warfare," Research Working Papers 6, MICROCON - A Micro Level Analysis of Violent Conflict.

Karlberg J (1987): “On the modelling of human growth”. Stat Med;6:185-192.

Karlberg J 1989): "A biologically-oriented mathematical model (ICP) for human growth." Acta Paediatr Scand Suppl;350:70-94.

Karlberg J, Engström I, Karlberg P, Fryer JG (1987a): "Analysis of linear growth using a mathematical model. I. From birth to three years". Acta Paediatr Scand;76:478-488.

Karlberg J, Fryer JG, Engström I, Karlberg P (1987b): "Analysis of linear growth using a mathematical model. II. From 3 to 21 years of age.” Acta Paediatr Scand Suppl;337:12-29. 
Karlberg P, Taranger J, Engström I, Karlberg J, Landstrom T, Lichtenstein H, Lindstrom B, Svennberg-Redegren I: (1976) "I. Physical growth from birth to 16 years and longitudinal outcome of the study during the same age period." Acta Paediatr Scand Suppl;258:7-76.

Karlberg, Johan; Kwan, Chi-wai; Gelander, Lars; Albertsson-Wikland, Kerstin.(2003) "Pubertal Growth Assessment.Preview" Hormone Research, Supplement 1, Vol. 60,

Komlos, J. (1999). On the Biological Standard of Living in Russia and the Soviet Union. Slavic Review 58(1): 71-79.

Loaiza, E. (1997). Maternal Nutritional Status. DHS Comparative Studies No. 24. Calverton, Maryland, Macro International Inc.

Martorell, R., K.L. Khan and D.G. Schroeder, "Reversibility of Stunting: Epidemiological Findings in Children from Developing Countries", European Journal of Clinical Nutrition, 1994, 48(suppl), S45-S57.

Martorell R, Habicht JP. (1986) "Growth in early childhood in developing countries". In: Falkner F, Tanner JM, editors. Human growth: a comprehensive treatise, vol. 3. 2nd ed. New York: Plenum Press,: 241-62

Moradi A. (2002), "Height and Health of Women in Sub-Saharan Africa and South-Asia 1950-1980". Paper presented at the XIII Congress of the International Economic History Association, Buenos Aires, Argentina.

Moradi, A. and Baten, J., (2005). "Inequality in Sub-Saharan Africa: New Data and New Insights from Anthropometric Estimates," World Development, Elsevier, vol. 33(8), pages 1233-1265, August.

Murdoch, J.C. and T. Sandler, (2002,) "Economic Growth, Civil Wars, and Spatial Spillovers," Journal of Conflict Resolution 46 (1): 91-110.

Pedersen, J. (2009), "Health and Conflict. A review of the links". Fafo-report, 2009:20

Robinson, D.A., Curse on the Land: A History of the Mozambican Civil War, (2006) PhD dissertation at School of Humanities The University of Western Australia

Saul, J.S. (ed). (1975) A Difficult Road: The Transition to Socialism in Mozambique, (New York: Monthly Review Press, 1985), , p45 (quoting Samora Machel's Independence Day speech at Machava Stadium, 25 June 1975).

Saul, J.S., "Inside from the Outside? The Roots and Resolution of Mozambique's Un/Civil War", in Taisier M. Ali and Robert O. Matthews (eds), Civil Wars in Africa: Roots and Resolution, (McGill-Queen's University Press: Montreal, 1999). p136.

Serapião, L B. "Mozambique's National Interest in the Regional Conflict of Southern Africa”,Conflict, Vol 9, No 4, 1990, pp341-356.

Shemyakina, O. (2006) "The Effect of Armed Conflict on Accumulation of Schooling: Results from Tajikistan." Households in Conflict Network Working Paper, 12. 
Singer, J. D, and Small.H.M. (1994). "Correlates of War Project: International and Civil War Data, 1816-1992.” ICPSR 9905, April.

Smith,I. (1997) The Great Betrayal, (London: Blake, 1997),

South African Foreign Affairs Archives "Staatkundlge Komitee: Voorgestelde Wysings Tov Strategie NR 19: Mosambiek", pp5-6.

Stewart, F. and Humphreys, F.P. (1997), "Civil conflict in developing countries over the last quarter century: an empirical overview of the economic and social consequences." Oxford Development Studies 1997; Vol. 25 Issue 1, p11, 31p.

Stiff, P.,(1999) “The Silent War: South African Recce Operations 1969-1994," (Alberton: Galago, 1999),

Tabeau, E. and Bijak, J. (2005), "War-related Deaths in the 1992-1995 Armed Conflicts in Bosnia and Herzegovina: A Critique of Previous Estimates and Recent Results", European Journal of Population 21(2-3): 187-215

Vines, A.(1991) “RENAMO: Terrorism in Mozambique,” (London: James Currey, 1991).

Vines, A.(1996) "RENAMO: From Terrorism to Democracy in Mozambique?" (London: James Currey, 1996)

Wilson, K. (1992) "Cults of Violence and Counter-Violence in Mozambique", Journal of Southern African Studies, Vol 18, No 3, September 1992, 


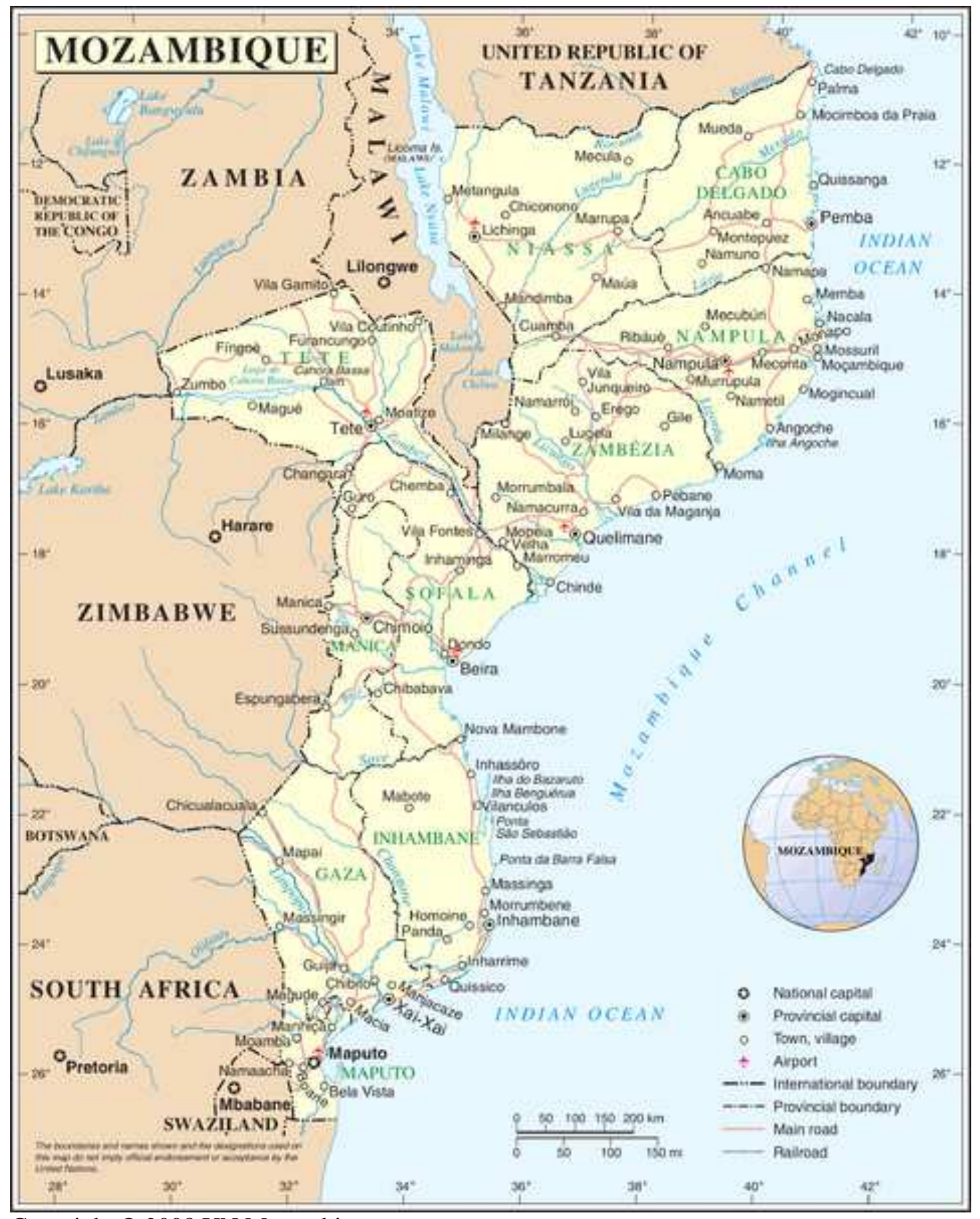

Copyright @ 2008 UN Mozambique.

Annex 2: Height for age z-score formula:

Observed Height/Age - Median Height/Age from the Reference Population

Height for age Z-score =

Standard deviation from the Reference Population 